\title{
RCSB Protein Data Bank: Structural biology views for basic and applied research
}

\author{
John Westbrook, RCSB Protein Data Bank
}

The RCSB Protein Data Bank (RCSB PDB, http://www.rcsb.org) provides rich structural views of biological systems to enable breakthroughs in scientific inquiry, medicine, drug discovery, technology, and education. The website offers multiple tools for structure query, analysis, and visualization (Berman et al., 2000; Rose et al., 2017).

Users can perform simple searches from the top search bar (e.g., ID, name, sequence, ligand) or build complex combinations of search parameters using Advanced Search. Information from DrugBank is integrated with PDB data to facilitate searches for drugs and drug targets. Other classification systems are used to organize PDB structures in hierarchical trees for browsing and searching (e.g., mpstruc, Gene Ontology, Enzyme Classification).

Visualization features include Protein Feature View, a graphic comparison of a PDB sequence with UniProt and other annotations; Gene View, a tool that illustrates the correspondences between the human genome and 3D structure; 3D visualization of electron density maps for bound ligands; and rapid visualization of large structures using the NGL viewer (Rose et al., 2016) (Shown: NGL view of Faustovirus protein PDB ID 5J7V).

The RCSB PDB is funded by a grant (DBI-1338415) from the National Science Foundation, the National Institutes of Health, and the US Department of Energy. RCSB PDB is a member of the Worldwide Protein Data Bank (http://wwpdb.org).

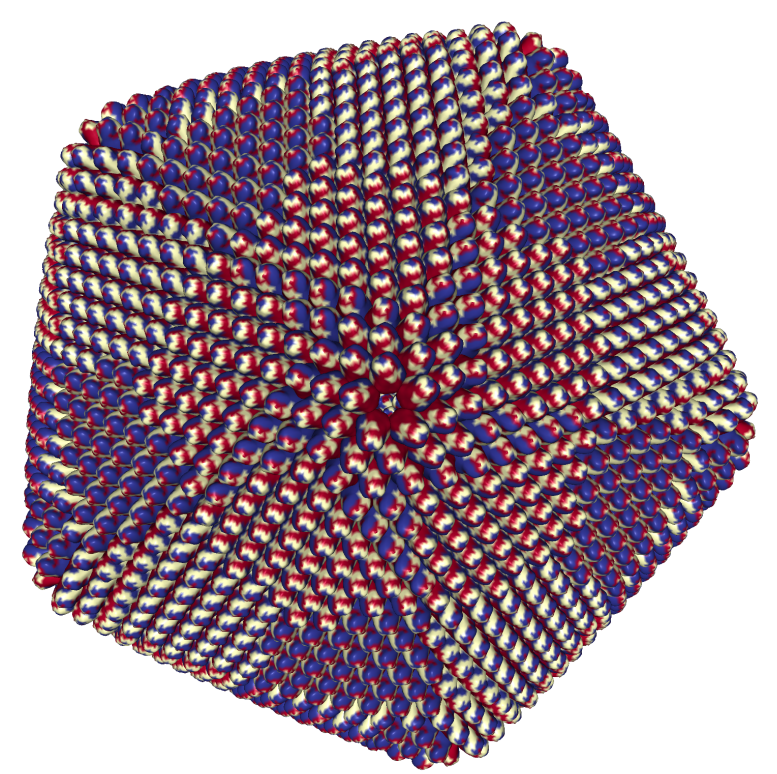

Berman, H. M., Westbrook, J., Feng, Z., Gilliland, G., Bhat, T. N., Weissig, H., Shindyalov, I. N. \& Bourne, P. E. (2000). Nucleic Acids Res 28, 235-242.

Rose, A. S., Bradley, A. R., Valasatava, Y., Duarte, J. M., Prlić, A. \& Rose, P. W. (2016). Proceeding Web3D '16 Proceedings of the 21st International Conference on Web3D Technology 185-186.

Rose, P. W., Prlic, A., Altunkaya, A., Bi, C., Bradley, A. R., Christie, C. H., Costanzo, L. D., Duarte, J. M., Dutta, S., Feng, Z., Green, R. K., Goodsell, D. S., Hudson, B., Kalro, T., Lowe, R., Peisach, E., Randle, C., Rose, A. S., Shao, C., Tao, Y. P., Valasatava, Y., Voigt, M., Westbrook, J. D., Woo, J., Yang, H., Young, J. Y., Zardecki, C., Berman, H. M. \& Burley, S. K. (2017). Nucleic Acids Res 45, D271-D281. 